\title{
Dietary Nutrient Manipulation to Improve the Performance and Tibia Characteristics of Broilers Fed Oak Acorn (Quercus Brantii LindI)
}

\section{-Author(s)}

Houshmand M

Hojati $F^{\prime}$

Parsaie $S^{\prime}$

Department of Animal Science, Faculty of Agriculture, University of Yasouj, Yasouj, Iran

\section{ABSTRACT}

An experiment was conducted to evaluate the effects of dietary nutrients (protein, methionine, and choline) manipulation on the performance and tibia characteristics of broilers fed diets containing $15 \%$ oak acorn. A completely randomized design with five treatments and four replicates of 15 chicks each, was used. One group was fed a diet based on corn (without oak acorn) as control and other four groups were fed diets containing oak acorn with one of the following nutrient manipulation: without nutrient manipulation, high level of methionine (100\% more than NRC), high level of CP (10\% more than NRC), and addition of $0.2 \%$ choline. Starter and finisher diets were fed from one to 21 and 22 to $42 \mathrm{~d}$ of age, respectively. The results indicated that group fed diet without nutrient manipulation presented higher feed intake and worse feed conversion ratio $(p<0.05)$ compared with the control group throughout the experiment. Elevated levels of methionine, protein, and choline had significant beneficial effects on feed conversion ratio during starter phase. Feeding oak acorn negatively influenced tibia bone characteristics (bone ash and strength) both at 21 and $42 \mathrm{~d}$ of age, whereas the supplementation with protein, methionine and choline prevented those negative effects. In conclusion, dietary inclusion of $15 \%$ oak acorn had negative effects on broiler performance and tibia characteristics. Detrimental effects of oak acorn, particularly on tibia bone, were reduced or prevented by increasing the dietary levels of choline, methionine, and protein.

\section{INTRODUCTION} Houshmand $M$

Department of Animal Science, Faculty of Agriculture, University of Yasouj, Yasouj, Iran - Postal code: 75918-74831

Tel: +987412224840

Fax: +987412224840

Mobile: +989171464147

E-mail: hooshmand@yu.ac.ir

\section{nKeywords}

Broiler, nutrient manipulation, oak acorn, performance, tibia.
In the animal and poultry production industry, the highest cost is related to nutrition. Corn is the main feedstuff of poultry diets. This feedstuff is mostly imported and thus it is expensive in importing countries, such as Iran. Therefore, looking for cheaper and local feedstuffs is of great importance in reducing production costs. Oak acorn, the seed of oak trees, is produced and available in large quantities in some countries of the world, including Iran. The nutrient composition of oak acorn is similar to that of cereal grains. Shimada (2001) reported that the main nutrients of two species of acorns were carbohydrate, protein, and fat and their main component was NFE (80-90\% DM). Due to high levels of carbohydrates (47-60\% starch) (Kekos \& Kaukios, 1985), oak acorn may potentially be used as an energy source and therefore, replace corn in broiler diets, such as the case in NorthAfrican countries (Bouderoua \& Selselet-Attou, 2003). There is limited information on the use of oak acorn in broiler nutrition. Bouderona et al. (2009) reported that broilers fed diets containing 35\% green oak acorn presented lower body weight compared with the control group at 35 $\mathrm{d}$ of age, but there was no difference between two groups at the end of the experiment (56 d of age). Although oak acorn may potentially 
be used in poultry nutrition, some factors may limit their inclusion in the diets. High levels of tannins (7.28$11.72 \%$ on dry matter basis) are present in oak acorn (Shimada, 2001). Because of their deleterious effects on poultry, tannins can be classified as anti-nutritional factors (Jansman, 1993), and their presence in animal diets is related with numerous nutritional problems (Butler, 1989). Many studies have shown that dietary tannins have negative effects on broilers (Sharif et al., 2012; Medugu et al., 2012; Hassan et al., 2003).

There is increasing demand for food. Thus, tanniferous plants and agro-industrial by-products have received more interest to use in animal diets (Makkar, 1999). Due to their importance, different physical and chemical methods have been used to reduce the amounts of tannins and therefore, to improve the nutritional value of tannin-rich feedstuffs (Medugu et al., 2012). Also, it has been suggested that dietary nutrient manipulation can alleviate the deleterious effects of tannins. For example, beneficial effects of supplemental methionine, choline, and other methyl group donors have been reported (Rayudu et al., 1970, Chang \& Fuller, 1964). In addition, dietary protein level can influence the effects of tannins (Jansman, 1993), thus, deleterious effects of tannins could be reduced or alleviated by increasing the level of dietary protein (Sell et al., 1983).

Tannins have adverse effects on mineral availability and absorption (Jansman, 1993). Findings of Hassan et al. (2003) indicated that feeding sorghum grain containing high levels of tannins, significantly decreased the apparent absorption of minerals including $\mathrm{Ca}, \mathrm{P}, \mathrm{Mg}, \mathrm{Na}, \mathrm{K}, \mathrm{Fe}$ and $\mathrm{Co}$. The role of dietary minerals, particularly calcium, in bone structure and health is well documented (Rath et al., 2000). Considering the negative effects of tannins on mineral utilization, it is expected that high tannin diets negatively influence bone structure and health. Elkin et al. (1978) reported that broilers fed with tanninrich diets had higher incidence of leg abnormalities than those fed low-tannin diets. They concluded that tannins can alter the bone formation process. To our knowledge, there is no information on the influence of dietary nutrient manipulation on the performance and tibia characteristics of broiler chickens fed diets containing oak acorn. Thus, the current experiment was conducted to evaluate above-mentioned effects.

\section{MATERIALS AND METHODS}

\section{Birds, diets, and experimental design}

All procedures used in the current experiment were approved by the Institution Animal Care Committee of

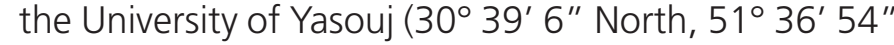
East). Three hundred one-day-old male and female broiler chicks (Cobb 500) with same initial weight (around $45 \mathrm{~g}$ ) were obtained from a local commercial hatchery. Upon arrival, birds were weighed as a group and randomly allocated to one of the five experimental diets (treatments) as follows: one group was fed diet based on corn (without oak acorn) as control (Ctrl), and other four groups were fed diets containing $15 \%$ oak acorn with one of the following nutrient manipulations: no nutrient manipulation (NM), high level of methionine (100\% more than NRC) (Met), high level of CP (10\% more than NRC) (HP), and addition of $0.2 \%$ choline (Cho). Each treatment had four replicates of 15 chicks each. Isocaloric diets were formulated according to NRC (1994) recommendations using the UFFDA software. The starter and finisher diets were offered as mash from 1-21 and 22-42 d of age, respectively (Table 1). Feed and water were provided ad libitum throughout the experiment. Birds were reared on floor pens and rice straw was used as litter. Oak acorns were collected in October 2012, from the forest of Yasouj, Kohgeluyeh and Bovir Ahmad Province, Iran. In the researched forest, Quercus brantii Lindl is the most common species. The seed coat of fruits were removed and fruits were dried in shadow and then fine grinded and included in the experimental diets.

Feed intake was calculated weekly on a pen basis. All birds in each pen were weighed weekly as a group and feed conversion ratio (FCR) was calculated. Mortality (around 4\% throughout the experiment) was recorded daily and FCR was adjusted for mortality.

Nutrient composition of oak acorn was determined according to the AOAC (1995). Acorns were firstly submitted to extraction to determine phenolic components. About $1 \mathrm{~g}$ ground oak acorn was accurately weighed and put in tubes and then, $3 \mathrm{~mL}$ of acetone (75\%) and $3 \mathrm{~mL}$ methanol (50\%) were added to the samples. The tubes were vortexed and then centrifuged $\left(3000 \mathrm{~g}\right.$ at $4^{\circ} \mathrm{C}$ ) for $20 \mathrm{~min}$. After that, the supernatant was removed and transferred to $2 \mathrm{~mL}$ tubes. The extracts were analyzed according to the procedure of Makkar (2003).

\section{Sampling and measurements}

On d 21 (end of starter phase) and 42 (end of finisher phase), one bird from each pen was sacrificed by cervical dislocation and its digestive system was immediately and carefully removed. The liver, pancreas, and abdominal fat pad were weighed. Their relative weights (organ weight/live weight $\times 100)$ were used for statistical analysis. At the same time (d 21 and 42 ), right and left 
Table 1 - Composition of the experimental diets

\begin{tabular}{|c|c|c|c|c|c|c|c|c|c|c|}
\hline \multirow[t]{2}{*}{ Ingredients (\%) } & \multicolumn{5}{|c|}{${ }^{1}$ Starter } & \multicolumn{5}{|c|}{${ }^{1}$ Finisher } \\
\hline & Ctrl & NM & Met & Cho & $\mathrm{HP}$ & Ctrl & NM & Met & Cho & HP \\
\hline Corn & 56.24 & 38.06 & 38.05 & 38.06 & 30.55 & 65.60 & 47.63 & 47.62 & 47.63 & 41.17 \\
\hline Oak acorn & $\ldots$ & 15 & 15 & 15 & 15 & $\ldots$ & 15 & 15 & 15 & 15 \\
\hline Soybean meal (44\% CP) & 34.21 & 35.99 & 35.99 & 35.99 & 42.38 & 27.37 & 29.1 & 28.62 & 29.1 & 34.65 \\
\hline Meat meal $(50 \%$ CP) & 3 & 3 & 3 & 3 & 3 & 2 & 2 & 2 & 2 & 2 \\
\hline Vegetable oil & 2.96 & 4.45 & 4.61 & 4.45 & 5.66 & 1.86 & 3.18 & 3.3 & 3.18 & 4.17 \\
\hline Limestone & 1.15 & 1.07 & 1.07 & 1.07 & 1.07 & 13 & 12.3 & 12.3 & 12.3 & 12.2 \\
\hline Dicalcium phosphate & 1.4 & 1.35 & 1.36 & 1.35 & 1.28 & 1.02 & 0.97 & 0.98 & 0.97 & 0.91 \\
\hline Common salt & 0.42 & 0.43 & 0.43 & 0.43 & 0.43 & 0.3 & 0.31 & 0.31 & 0.31 & 0.31 \\
\hline${ }^{2}$ Vitamins premix & 0.25 & 0.25 & 0.25 & 0.25 & 0.25 & 0.25 & 0.25 & 0.25 & 0.25 & 0.25 \\
\hline${ }^{3}$ Minerals premix & 0.25 & 0.25 & 0.25 & 0.25 & 0.25 & 0.25 & 0.25 & 0.25 & 0.25 & 0.25 \\
\hline DL-Methionine & 0.13 & 0.15 & 0.63 & 0.15 & 0.13 & 0.06 & 0.08 & 0.44 & 0.08 & 0.06 \\
\hline Choline chloride & $\ldots$ & $\ldots$ & $\ldots$ & 0.2 & $\ldots$ & $\ldots$ & $\ldots$ & $\ldots$ & 0.2 & $\ldots$ \\
\hline \multicolumn{11}{|l|}{ Analysis results } \\
\hline ME (Kcal/kg) & 3000 & 3000 & 3000 & 3000 & 3000 & 3000 & 3000 & 3000 & 3000 & 3000 \\
\hline Crude protein, \% & 21.56 & 21.56 & 21.56 & 21.56 & 23.72 & 18.75 & 18.75 & 18.75 & 18.75 & 20.63 \\
\hline Calcium, $\%$ & 0.94 & 0.94 & 0.94 & 0.94 & 0.94 & 0.85 & 0.85 & 0.85 & 0.85 & 0.85 \\
\hline Available P., \% & 0.42 & 0.42 & 0.42 & 0.42 & 0.42 & 0.33 & 0.33 & 0.33 & 0.33 & 0.33 \\
\hline Lysine, \% & 1.03 & 1.03 & 1.03 & 1.03 & 1.03 & 0.94 & 0.94 & 0.94 & 0.94 & 0.94 \\
\hline Methionine, \% & 0.47 & 0.47 & 0.94 & 0.47 & 0.47 & 0.36 & 0.36 & 0.72 & 0.36 & 0.36 \\
\hline
\end{tabular}

${ }^{1}$ Ctrl: Control diet (based on corn, without oak acorn), NM: Diet containing oak acorn without any nutrient manipulation, Met: Diet containing oak acorn with high level of methionine (100\% more than NRC), Cho: Diet containing oak acorn added with 0.2\% choline, HP: Diet containing oak acorn with high level of CP (10\% more than NRC).

${ }^{2}$ The vitamin premix supplied the following per kilogram of diet: vitamin A (retinyl acetate), 8,000 IU; vitamin D3, 1,000 IU; vitamin E (dl- $\alpha$-tocopherol), 30 IU; vitamin K3, 2.5 mg; vitamin B1, 2 mg; vitamin B2, 5 mg; vitamin B6, 2 mg; vitamin B12, 0.01 mg; niacin, 30 mg; d-biotin, 0.045 mg; vitamin C, $50 \mathrm{mg}$; d-pantothenate, 8 mg, folic acid, 0.5 mg.

${ }^{3}$ The mineral premix supplied the following per kilogram of diet: Mn, 70 mg; Fe, 35 mg; Zn, 70 mg; Cu, 8 mg; I, 1 mg, Se, 0.25 mg; Co, 0.2 mg.

tibias were removed as drumsticks. Drumsticks were boiled for $10 \mathrm{~min}$. After cooling, bones were manually defleshed and dried for $24 \mathrm{~h}$ at room temperature. Right and left tibia bones were used to determine the tibia breaking strength and ash, respectively. Tibia length, weight, and volume were accurately determined. Tibia breaking strength (breaking force divided by bone weight) was measured using an Instron Universal Tester Machine with a 50-kg load cell at 50-kg load range with a crosshead speed of $50 \mathrm{~mm} / \mathrm{min}$. Supports were placed at tibia epiphysis and the force was applied in central fraction (Park et al., 2003).

In order to determine bone ash, tibia bones were dried at $105^{\circ} \mathrm{C}$ for $24 \mathrm{~h}$ and then put in a furnace at $550^{\circ} \mathrm{C}$ for $24 \mathrm{~h}$. Bone ash was calculated based on the dry weight of the tibia. Tibia ash weight/tibia bone length index was calculated by dividing the tibia ash weight by its length (Seedor et al., 1991). Tibia robusticity index was calculated using following formula: Robusticity index = tibia length/cube root of tibia weight (Reisenfeld, 1972).

Data were submitted to analysis of variance using the General Linear Models (GLM) procedures of SAS software (2005). Means were compared by Duncan's Multiple Range Test. The level of statistical significance was set at $p<0.05$.

\section{RESULTS}

\section{Nutrient composition of oak acorn}

As expected, the results indicated that nitrogenfree extract (NFE) was the main component of oak acorn (Table 2). In addition, high levels of tannins were detected.

Table 2 - Proximate analysis and phenolics components of oak acorn

\begin{tabular}{|c|c|c|c|c|c|c|c|c|}
\hline Component & ash & $C P$ & $\mathrm{EE}$ & $C F$ & NFE & TP & $\mathrm{TT}$ & NTP \\
\hline Value (\% DM) & 1.06 & 5.03 & 11.67 & 5.20 & 73.52 & 10.58 & 6.06 & 4.52 \\
\hline
\end{tabular}




\section{Performance}

The effects of experimental treatments on broiler performance (body weight gain (BWG), feed intake (FI) and feed conversion ratio (FCR)) are shown in Table 3. The findings indicate that there was no difference between the Ctrl and NM group in BWG, throughout the experiment $(p>0.05)$. On the other hand, dietary inclusion of oak acorn had no detrimental effect on BWG. Birds fed the diet containing high level of protein (HP group) were heavier than those fed the other treatment diets (except for the Cho group at 1-21 d of age) during all phases of the experiment (1-21, 22-42 and 1-42 d of age). The supplementation with choline significantly increased BWG during 1-21 and 1-42 d of age relative to the NM group. Elevated levels of methionine had no effect on BWG ( $p>0.05)$. All groups fed diets containing oak acorn presented higher FI than the Ctrl group during the starter and finisher phases and during the entire experimental period $(p<$ 0.05). The dietary inclusion of oak acorn negatively influenced FCR; therefore, the NM group had worse FCR compared with the Ctrl group throughout the experiment.

During starter phase (1-21 d of age), FCR was not different among the $\mathrm{Ctrl}$ and manipulated groups (Met, Cho and HP groups) ( $p>0.05)$. These results indicate that increasing the level of these nutrients have beneficial effects and can alleviate the adverse effects of oak acorn and of its anti-nutritional factors, such as tannins. The HP group (birds fed high protein diets) had better FCR than the NM group, during 1-21 and 1-42 d of age.

\section{Tibia characteristics}

The results of experimental treatments on tibia characteristics at 21 and $42 \mathrm{~d}$ of age (Table 4), indicate that on $d 21$, differences in length, volume and robusticity index were not observed among treatments ( $p>0.05)$. Tibia ash was lower in the NM group than the Ctrl group $(p<0.05)$, while dietary addition of all nutrients (protein, methionine and choline) increased tibia ash compared with the NM group $(p<0.05)$ and hence, their tibia ash content was similar to that of the Ctrl group. Interestingly, same results were observed for bone strength. Birds of the NM group presented lower bone strength values than the $\mathrm{Ctrl}$ group, while there was no difference between the Ctrl and manipulated groups ( $p>0.05)$.

On $d 42$, there were no differences among treatments for tibia length, volume, weight, or and two bone indexes $(p>0.05)$. Similarly to the results obtained at $21 \mathrm{~d}$ of age, the NM group had lower tibia ash content and strength compared with the Ctrl group.

\section{Abdominal fat pad, liver, and pancreas weights}

The results indicated that abdominal fat pad, liver, and pancreas weights were not influenced by the dietary treatments $(p>0.05)$ (data are not shown).

Table 3 - Effects of experimental treatments on body weight gain, feed intake, and feed conversion ratio of broilers at different phases of the experiment

\begin{tabular}{|c|c|c|c|c|c|c|}
\hline \multirow[t]{2}{*}{ Parameter } & \multicolumn{6}{|c|}{${ }^{1}$ Experimental treatments } \\
\hline & Ctrl & NM & Met & Cho & HP & SEM \\
\hline \multicolumn{7}{|c|}{ Body weight gain (g) } \\
\hline d $1-21$ & $489^{b}$ & $475^{b}$ & $484^{b}$ & $601^{a}$ & $597^{a}$ & 12 \\
\hline d 22-42 & $1175^{b}$ & $1107^{b}$ & $1132^{\mathrm{b}}$ & $1147^{b}$ & $1410^{a}$ & 47 \\
\hline d $1-42$ & $1663^{\text {bc }}$ & $1582^{c}$ & $1616^{\mathrm{bc}}$ & $1748^{b}$ & $2007^{a}$ & 48 \\
\hline \multicolumn{7}{|c|}{ Feed intake (g) } \\
\hline d $1-21$ & $924^{d}$ & $1046^{\mathrm{bc}}$ & $986^{\mathrm{bc}}$ & $1179^{a}$ & $1122^{\mathrm{ab}}$ & 36 \\
\hline d 22-42 & $2214^{c}$ & $2890^{b}$ & $3061^{\mathrm{ab}}$ & $3182^{\mathrm{ab}}$ & $3285^{a}$ & 109 \\
\hline d $1-42$ & $3137^{c}$ & $3639^{b}$ & $4047^{\mathrm{ab}}$ & $4360^{a}$ & $4406^{a}$ & 126 \\
\hline \multicolumn{7}{|c|}{ Feed conversion ratio } \\
\hline d 1-21 & $1.88^{b}$ & $2.20^{\mathrm{a}}$ & $2.03^{\mathrm{ab}}$ & $1.97^{\mathrm{ab}}$ & $1.87^{\mathrm{b}}$ & 0.074 \\
\hline d 22-42 & $1.89^{c}$ & $2.60^{\mathrm{ab}}$ & $2.70^{a}$ & $2.78^{a}$ & $2.33^{b}$ & 0.094 \\
\hline d $1-42$ & $1.88^{c}$ & $2.48^{a}$ & $2.50^{\mathrm{a}}$ & $2.49^{a}$ & $2.19^{b}$ & 0.069 \\
\hline
\end{tabular}

Means within a row with different superscript letters are significantly different at $p<0.05$.

${ }^{1}$ Ctrl: Control diet (based on corn, without oak acorn), NM: Diet containing oak acorn without any nutrient manipulation, Met: Diet containing oak acorn with high level of methionine (100\% more than NRC), Cho: Diet containing oak acorn added with $0.2 \%$ choline, HP: Diet containing oak acorn with high level of CP (10\% more than NRC). 
Table 4 - Effects of experimental treatments on tibia characteristics of broilers at 21 and $42 \mathrm{~d}$ of age

\begin{tabular}{|c|c|c|c|c|c|c|}
\hline \multirow[t]{2}{*}{ Parameter } & \multicolumn{6}{|c|}{${ }^{1}$ Experimental treatments } \\
\hline & Ctrl & NM & Met & Cho & $\mathrm{HP}$ & SEM \\
\hline \multicolumn{7}{|c|}{ Weight (g) } \\
\hline$d 21$ & $1.8^{\mathrm{b}}$ & $1.9^{b}$ & $2.1^{\mathrm{ab}}$ & $2.2^{\mathrm{a}}$ & $1.9^{\mathrm{b}}$ & 0.09 \\
\hline d 42 & 5.7 & 5.9 & 6.1 & 6.5 & 7 & 0.45 \\
\hline \multicolumn{7}{|c|}{ Length $(\mathrm{cm})$} \\
\hline $\mathrm{d} 21$ & 6.2 & 6.1 & 6.3 & 6.2 & 6.2 & 0.07 \\
\hline $\mathrm{d} 42$ & 9.4 & 9.4 & 9.3 & 9.5 & 9.4 & 0.13 \\
\hline \multicolumn{7}{|c|}{ Volume (mL) } \\
\hline $\mathrm{d} 21$ & 2.5 & 2.5 & 3.5 & 3.5 & 3.2 & 0.38 \\
\hline d 42 & 8.5 & 7.2 & 8 & 7.8 & 8.8 & 0.8 \\
\hline \multicolumn{7}{|c|}{ Ash (\%) } \\
\hline $\mathrm{d} 21$ & $41.9^{a}$ & $40.7^{b}$ & $42.5^{a}$ & $41.5^{a}$ & $43.3^{\mathrm{a}}$ & 1.1 \\
\hline $\mathrm{d} 42$ & $45.3^{a}$ & $39^{b}$ & $41.7^{\mathrm{ab}}$ & $40.8^{\mathrm{ab}}$ & $41.6^{\mathrm{ab}}$ & 1.36 \\
\hline \multicolumn{7}{|c|}{ Strength $\left(\mathrm{kg} / \mathrm{m}^{2}\right)$} \\
\hline $\mathrm{d} 21$ & $27^{\mathrm{ab}}$ & $15.5^{c}$ & $28.5^{a}$ & $20.5^{b c}$ & $21.7^{b c}$ & 2.9 \\
\hline $\mathrm{d} 42$ & $43^{a}$ & $25^{b}$ & $33^{\mathrm{ab}}$ & $31^{\mathrm{ab}}$ & $34.5^{\mathrm{ab}}$ & 3.86 \\
\hline \multicolumn{7}{|c|}{${ }^{2} \mathrm{~W} / \mathrm{L}(\mathrm{mg} / \mathrm{mm})$} \\
\hline $\mathrm{d} 21$ & $9.9^{b}$ & $13.8^{\mathrm{a}}$ & $11.9^{\mathrm{ab}}$ & $13^{a}$ & $13.1^{\mathrm{a}}$ & 0.71 \\
\hline $\mathrm{d} 42$ & 25.2 & 20.3 & 22.9 & 23.4 & 25.6 & 2.8 \\
\hline \multicolumn{7}{|c|}{ Robusticity index } \\
\hline $\mathrm{d} 21$ & 5.4 & 5.6 & 5.4 & 5.4 & 5.3 & 0.13 \\
\hline$d 42$ & 5.3 & 5.2 & 5.1 & 5.2 & 5.1 & 0.08 \\
\hline
\end{tabular}

Means within a row with different superscript letters are significantly different at $p<0.05$.

${ }^{1}$ Ctrl: Control diet (based on corn, without oak acorn), NM: Diet containing oak acorn without any nutrient manipulation, Met: Diet containing oak acorn with high level of methionine (100\% more than NRC), Cho: Diet containing oak acorn added with $0.2 \%$ choline, HP: Diet containing oak acorn with high level of CP (10\% more than NRC).

${ }^{2}$ W/L: tibia ash weight / tibia length index

\section{DISCUSSION}

There are limited data in literature regarding the effects of oak acorn on broilers and poultry performance. The results of the current experiment indicated that dietary inclusion of $15 \%$ oak acorn had no adverse effect on BWG. These results are in agreement with the findings of Kaushal \& Singh (1982), who reported that dietary inclusion of oak acorn at the rates of 10 and $15 \%$ had no detrimental effects on body weight gain, while 20 and $25 \%$ acorn significantly decreased BWG.

There are conflicting results on the influence of tannins on feed intake. Similar with our results, Nyachoti et al. (1996) reported an increase in the feed intake of broilers fed a high-tannin sorghum diet. As the AMEn value of the high-tannin diet was significantly reduced, those authors concluded that the increase in feed intake may reflect an attempt to compensate for reduced energy availability. Conversely, Hassan et al. (2003) reported that tannic acid significantly reduced broiler feed intake. The mechanisms by which tannins affect feed intake are not well understood. Tannins can attach to salivary proteins and cause dryness in the mouth, causing a stringent or bitter taste that affects diet palatability and hence, decrease feed intake. It should be mentioned that chickens have very few taste buds (around 24) in their mouth, and therefore, diet taste has probably no important effect on bird feed intake (Nyachoti et al., 1996).

Adverse effects of high-tannin diets on broiler performance have previously been reported by many researchers (Sharif et al., 2012; Medugu et al., 2012; Hassan et al., 2003). The main effects of tannins are related to their protein-binding capacity, thereby reducing protein digestibility, particularly in monogastric animals. In addition, tannins have negative effects on starch and energy digestion in poultry and pigs (Jansman, 1993). Tannins increase endogenous amino acid loss. They also have negative effects on the parotid glands and gastrointestinal mucus, intestinal villi height, and liver cells (Ortiz et al., 1994), dietary 
metabolizable energy and efficiency of nitrogen utilization (Nyachoti et al.,1996). Inhibitory effects on the activity of digestive enzymes, such as $\alpha$-amylase, $\beta$-amylase, trypsin, lipase, and $\beta$ - glucosidase (Jansman, 1993) have been shown.

The results of the current experiment suggest that supplementation with protein, methionine, and choline may potentially reduce the deleterious effects of tannins and therefore are in line with those reported by other researchers (Chang \& Fuller, 1964; Rayudu et al., 1970). Armstrong et al. (1973) found that feeding with high-tannin diets impaired broiler performance (growth and feed efficiency), but the dietary methionine supplementation alone and in combination with choline significantly reduced the negative effects of tannins and improved birds performance. In contrast, Wareham et al (1991) reported that dietary methionine levels had no significant effects on fava bean tannins. They concluded that methionine does not act as a specific detoxifier of fava bean tannins. It has been shown that tannic acid is hydrolyzed to gallic acid. A high portion of this compound is methylated and excreted in the urine as 4-0-methyl gallic acid. On the other hand, methyl groups are needed for methylation of gallic acid. This is a possible explanation why the dietary supplementation with methionine, choline, and other methyl group donors have beneficial effects on the birds fed with tannic acid-rich diets (Potter \& Fuller, 1968).

The results showed that high protein diets reduced the negative effects of high-tannin diet. As mentioned earlier, tannins can attach to proteins. High levels of dietary protein can alleviate the effects of tannins by two mechanisms: 1- provide limiting amino acids, which availability is reduced by tannins, and 2- provide more protein to complex with tannins and thereby reducing some other toxic effects of tannin (Sell et al., 1983). However, due to two major problems (environmental pollution and economic issues), feeding high-protein diets is not recommended (Aftab et al., 2006). Thus, it seems that supplementation with choline and methionine are more practical strategies to improve the nutritional value of oak acorn and to allow its use as an alternative to corn in broiler nutrition.

Different parameters can be used to determine bone mineralization and hence bone structure and health in poultry, including bone ash, bone breaking strength, bone weight, and bone volume (Rao et al., 1993). Also, bone density is evaluated by two indexes: 1- the bone ash weight/bone length index, where higher values indicate more density (Monteagudo et al., 1997), and 2- robusticity index, where lower values indicate stronger bones (Reisenfeld, 1972). The current results suggest that dietary inclusion of oak acorn (containing high levels of tannins) had detrimental effects on tibia characteristics (ash and strength) at 21 and $42 \mathrm{~d}$ of age. Dietary minerals play important roles in bone structure and health (Rath et al., 2000). Mineral availability and absorption are negatively influenced by tannins (Jansman, 1993; Hassan et al., 2003). Thus, reductions in tibia bone ash and strength could be attributed to the presence of the high levels of tannins in oak acorn. The results indicated that increasing the dietary levels of protein, methionine, and choline prevented detrimental effects of oak acorn on tibia bone. As previously discussed, all these nutrients may potentially reduce or eliminate the negative effects of tannins. The negative effects of high-tannin diets on the incidence and severity of leg abnormalities have previously been reported by other researchers (Elkin et al. 1978; Rostagno et al., 1973).

The results indicate that the pancreas, liver and abdominal fat pad were not significantly influenced by the dietary treatments. In line with our results, Nyachoti et al. (1996) reported that tannins had no significant effect on liver and pancreas weight. They suggested that source of tannin can be considered as an important factor. Previously, it was reported that high tannin diets have inhibitory effects on pancreatic enzymes activities. Thus, the pancreas needs to increase enzyme production, resulting in pancreatic hypertrophy (Ahmed et al., 1991). It should be considered that effects of tannins are influenced by different factors such as the response parameters chosen (weight gain, feed intake, and feed efficiency), source and concentration of tannins, animal factors (species, age, and production level), and diet composition (Jansman, 1993).

In conclusion, dietary inclusion of $15 \%$ oak acorn had negative effects on broiler performance and tibia characteristics. These negative effects could be alleviated or prevented by increasing the levels of dietary choline, methionine, and protein. It is concluded that oak acorn may potentially be used in broiler diets, but the level of some dietary nutrients should be increased. In addition, more studies on the type, level, and possible role of dietary nutrients in reducing the negative effects of oak acorn are needed.

\section{ACKNOWLEDGMENTS}

This research was supported by Yasouj University, Yasouj, Iran. 


\section{REFERENCES}

Aftab U, Ashraf M, Jiang Z. Low protein diets for broilers. World's Poultry Science Journal 2006;62:688-698.

Ahmed AE, Smithard R, Ellis M. Activities of enzymes of the pancreas, and the lumen and mucosa of the small intestine in growing broiler cockerels fed on tannin-containing diets. British Journal of Nutrition 1991;65:189-197.

Armstrong WD, Featherston WR, Rogler JC. Influence of methionine and other dietary additions on the performance of chicks fed bird resistant sorghum grain diets. Poultry Science 1973;52:1592-1599.

AOAC - Association of Official Analytical Chemists. Official methods of analysis. 16th ed. Washington; 1995.

Bouderoua K, Mourot J, Selselet-Attou G. The effect of green oak acorn (Quercus ilex) based diet on growth performance and meat fatty acid composition of broilers. Asian-Australasian Journal of Animal Science 2009;6:843-848

Bouderoua K, Selselet-Attou G. Fatty acid composition of abdominal adipose tissue in broilers fed green-oak (Quercusilex), cork oak acorn (Quercus Suber L.) based diets. Animal Research 2003;52:377-382.

Butler LG. Effects of condensed tannin on animal nutrition. In: Hemingway RW, Karchesy JJ, Branham SJ, editors. Chemistry and significance of condensed tannin. New York: Plenum Press; 1989.

Chang IS, Fuller LH. Effects of tannin content of grain sorghum on their feeding value for growing chicks. Poultry Science 1964;43:30-36.

Elkin RG, Featherston WR, Rogler JC. Investigations of leg abnormalities in chicks consuming high tannin sorghum grain diets. Poultry Science 1978; $57: 757-762$.

Hassan IAG, Elzubeir EA, El Tinay AH. Growth and apparent absorption of minerals in broiler chickens fed diets with low and high tannin contents. Tropical Animal Health and Production 2003;35:189-196.

Jansman AJM. Tannins in feedstuffs for simple-stomached animals. Nutrition Research Reviews 1993;6:209-236.

Kaushal NA, Singh B. Potentials of (Quercus leucotrichophora) A. Camus ex Bahadur acorns in poultry feed. Journal Tree Science 1982; 1:120-122.

Kekos D, Kaukios B. Acid hydrolysate of acorn polysacharid as substrates of Candida utilisis growth. Biotechnology 1985;7:345-348.

Makkar HPS. Evaluation and enhancement of feeding value of tanniniferous feeds. Tannins in livestock and human nutrition. Proceedings of an International Workshop; 1999; Adelaide. Australia. p.52-56.

Makkar HPS. Quantification of tannins in tree and shrub foliage. A laboratory manual. Washington: FAO/IAEA; 2003.

Medugu Cl, Saleh B, Igwebuike JU, Ndirmbita RL. Strategies to improve the utilization of tannin-rich feed materials by poultry. International Journal of Poultry Science 2012;11:417-423.

Monteagudo MD, Hernandez ER, Seco C, Gonzales-Riola J, Revilla M, Villa LF, Rico H. Comparison of the bone robusticity index and bone weight/bone length index with the results of bone densitometry and bone histomorphometry in experimental studies. Acta Anatomica 1997;160:195-199.

NRC. Nutrient Requirements of Poultry. Washington: National Academy Press; 1994.

Nyachoti CM, Atkinson JL, Lesson S. Response of broiler chicks fed a hightannin sorghum diets. Journal of Applied Poultry Research 1996;5:239245

Ortiz LT, Alzueta C, Trevino J, Castano M. Effects of faba bean tannins on the growth and histological structure of the intestinal tract and liver of chicks and rats. British Poultry Science 1994; 35:743-754

Park SY, Birkhold SG, Kubena LF, Nisbet DJ, Ricke SC. Effect of storage condition on bone breaking strength and bone ash in laying hens at different stages in production cycles. Poultry Science 2003;82:16881691.

Potter DK, Fuller HL. Metabolic fate of dietary tannins in chicks. Journal of Nutrition 1968;96:187-191.

Rao SK, West MS, Frost TJ, Orban JI, Bryant MM, Roland SR DA. Sample size required for various methods of assessing bone status in commercial leghorn hens. Poultry Science 1993;72:229-235.

Rath NC, Huff GR, Huff WE, Balog JM. Factors regulating bone maturity and strength in poultry. Poultry Science 2000;79:1024-1032.

Rayudu GVN, Kadirvel R, Vohra P, Kratzer FH. Toxicity of tannic acid and its metabolities for chickens. Poultry Science 1970;49:957- 960.

Reisenfeld A. Metatarsal robusticity in bipedal rats. American Journal of Physical Anthropology 1972;40:229-234.

Rostagno HS, Feptberston WR, Rogkr JC. Studies on the nutritional value of sorghum grains with varying tannin contents for chicks: Growth studies. Poultry Science 1973;52:765-772.

SAS. User's guide. Version 9. Cary: SAS Institute; 2005

Seedor JG, Quarruccio HA, Thompson DD. The bisphosphonate alendronate (MK-217) inhibits bone loss due to ovariectomy in rats. Journal of Bone and Mineral Research 1991;6:339-346

Sell DR, Rogler JC, Featherston WR. The effects of sorghum tannin and protein level on the performance of laying hens maintained in two temperature environments. Poultry Science 1983;62:2420-2428.

Sharif M, Idrees M, Tauqir NA, Shahzad MA, Khalid MF, Nisa M, Sarwar M, Khan ML. Effect of water treatment of sorghum on the performance of broiler chicks. South African Journal of Animal Science 2012;42:189194.

Shimada T. Nutrient compositions of acorns and horse chestnuts in relation to seed-hoarding. Ecological Research 2001;16:803-808.

Wareham CN, Wiseman J, Cole DJA. Craigon, J. The possible role of methionine in the detoxification of faba bean (Vicia faba L.) tannins in chick diets. British Poultry Science 1991;32:1017-1026. 
